\title{
Low-technology recirculating aquaculture system integrating milkfish Chanos chanos, sea cucumber Holothuria scabra and sea purslane Sesuvium portulacastrum
}

\author{
Paula Senff ${ }^{1,2, *}$, Pierre-Philippe Blanc ${ }^{3}$, Matthew Slater ${ }^{4}$, Andreas Kunzmann ${ }^{1}$ \\ ${ }^{1}$ Leibniz Centre for Tropical Marine Research, 28359 Bremen, Germany \\ ${ }^{2}$ University of Bremen, 28359 Bremen, Germany \\ ${ }^{3}$ Food and Agricultural Organization of the United Nations, 00153 Rome, Italy \\ ${ }^{4}$ Alfred Wegener Institute, Helmholtz Centre for Polar and Marine Research, 27515 Bremerhaven, Germany
}

\begin{abstract}
Closed recirculation aquaculture systems (RAS) in combination with integrated multitrophic aquaculture (IMTA) are considered best management practices, but high material costs and difficult maintenance still hinder their implementation, especially in developing countries and the tropics. Few case studies of such systems with tropical species exist. For the first time, an extremely low-budget system was tested combining the halophyte sea purslane Sesuvium portulacastrum and a detritivore, sandfish Holothuria scabra, with finfish milkfish Chanos chanos over 8 wk on Zanzibar, Tanzania. In a $2 \mathrm{~m}^{3} \mathrm{RAS}$, milkfish and sea purslane showed good growth, producing an average $( \pm$ SD) of $1147 \pm 79 \mathrm{~g}$ fish and $1261 \pm 95 \mathrm{~g}$ plant biomass, while sea cucumber growth was variable at $92 \pm 68 \mathrm{~g}$. The system operated without filter units and did not discharge any solid or dissolved waste. Water quality remained tolerable and ammonia levels were reliably decreased to $<1 \mathrm{mg} \mathrm{l}^{-1}$. $\mathrm{A} \mathrm{NO}_{2}{ }^{-}$peak occurred within the first $30 \mathrm{~d}$, indicating good biofilter performance of the different system compartments. Changes in dissolved inorganic nitrogen (DIN) species support the notion that the sea cucumber tank was the main site of nitrification, while the hydroponic halophyte tank acted as a net sink of $\mathrm{NO}_{3}{ }^{-}$. A nitrogen budget accounted for $63.7 \pm$ $5.3 \%$ of the nitrogen added to the system as fish feed. Increasing the plant to fish biomass ratio to 5:1 would fully treat the DIN load. The experiment provides proof-of-concept of a simple pilotscale RAS, integrating tropical species at 3 trophic levels.
\end{abstract}

KEY WORDS: IMTA $\cdot$ Appropriate technology $\cdot$ Halophyte $\cdot$ Biofilter $\cdot$ Nitrification $\cdot$ Denitrification Nitrogen budget

\section{INTRODUCTION}

Aquaculture is expanding rapidly but with significant environmental impacts (Holmer et al. 2003, Primavera 2006, Herbeck et al. 2014). Closed recirculation aquaculture systems (RAS) in combination with integrated multi-trophic aquaculture (IMTA) offer an example of extremely low-impact aquaculture (Schneider et al. 2005, Chopin et al. 2007). However,

${ }^{*}$ Corresponding author: paula.senff@leibniz-zmt.de high material costs, difficult maintenance and inadequate legislation still hinder their implementation, especially in the developing tropics (Chopin 2017, Kleitou et al. 2018, Stenton-Dozey et al. 2020). There is a dearth of research into low-cost and low-technology IMTA/RAS for tropical aquaculture-producing nations, and few case studies of such systems with tropical species exist (Largo et al. 2016, Felaco et al. 2020). Candidate species and, above all, local species

(1) The authors 2020. Open Access under Creative Commons by Attribution Licence. Use, distribution and reproduction are unrestricted. Authors and original publication must be credited. 
combinations including valuable extractive species remain poorly identified (Ahmed \& Glaser 2016, Zhang et al. 2019).

Halophytes are a possible extractive species for integrated aquaculture, but research focusing on them in this context has been limited (Custódio et al. 2017). As our agricultural food production is heavily reliant on glycophytes (plants that cannot tolerate salt), salttolerant halophytes are promising as vegetable crops or biomass for biofuel production (Buhmann \& Papenbrock 2013). Different plant species and types of natural and constructed wetlands are already being successfully used for phytoremediation of municipal and industrial wastewater or contaminated soil (Verhoeven \& Meuleman 1999, Vymazal 2010). Their use can have great economic benefits compared to conventional water treatment, as some species are nutritious and desired on the gourmet market (Cardoch et al. 2000, Ventura et al. 2011). Sesuvium portulacastrum, or sea purslane, is a perennial halophyte with potential as a valuable crop for saline soils (Lonard \& Judd 1997, Lokhande et al. 2009). In several countries, $S$. portulacastrum is consumed fresh or raw and is used as a traditional medicinal plant (Magwa et al. 2006, Lokhande et al. 2009). S. portulacastrum is already used to remediate saline soils and extract toxic textile dyes from discharge water (Patil et al. 2012). Very little is known about its nutrient tolerance and biofiltration capacity, but previous studies suggest that it can also remediate aquaculture wastewater (Slama et al. 2006, Boxman et al. 2017).

Sea cucumbers are particularly promising for integrated aquaculture, as some species have been found to feed and grow on the debris of fish farms (review by Zamora et al. 2018). Furthermore, they can be of high economic value and have beneficial effects on sediments by re-working upper sediment layers and influencing the development of microbial communities (Moriarty et al. 1985, Wolkenhauer et al. 2010, MacTavish et al. 2012). The detritivorous sea cucumber Holothuria scabra, also known as sandfish, is among the most valuable species, with increasing aquaculture production as many wild populations have been decimated (Lane \& Limbong 2015, Purcell et al. 2018, Hair et al. 2019). Global sandfish production in 2018 totaled 489 tons with a value of more than 2.5 million USD (FAO 2020). H. scabra has been studied as an IMTA species because it could prevent sediments from becoming anoxic under high loads of organic matter (Lee et al. 2017). In an experiment in the open sea, sandfish were not effective at remediating pollution from milkfish cultivation (Watanabe et al. 2017), but $H$. scabra can be integrated into sediment-based effluent treatment systems (Robinson et al. 2016) and be fed aquaculture waste to produce additional biomass (Robinson et al. 2019).

RAS are tank-based aquaculture facilities in which water from fish or shrimp cultivation is circulated to filtration units, requiring minimal water exchange, limiting the influence of environmental conditions on the cultivated species and potentially eliminating organic pollution. RAS technology is regarded as an important component of a sustainable future for aquaculture, moving towards closed cultivating systems (Martins et al. 2010, Yogev et al. 2017, Suantika et al. 2020). As closed aquaculture systems do not dispose of waste products of animal metabolism through water exchanges, they rely on bacteria to process elemental fluxes and particles (Blancheton et al. 2013). Nitrifying biofilters are a well-established component of RAS, where communities of nitrifying bacteria develop in RAS biofilters over time, oxidizing ammonia to $\mathrm{NO}_{2}{ }^{-}$and further to $\mathrm{NO}_{3}{ }^{-}$, causing $\mathrm{NO}_{2}{ }^{-}$peaks followed by increases in $\mathrm{NO}_{3}{ }^{-}$(Keuter et al. 2017, Brailo et al. 2019). Denitrification can be accomplished in RAS through a number of biological processes, summarized by van Rijn et al. (2006). In the process of assimilatory $\mathrm{NO}_{3}{ }^{-}$reduction, organisms such as plants, fungi or bacteria use $\mathrm{NO}_{3}{ }^{-}$as a source of nitrogen $(\mathrm{N})$, with efficiencies depending on the availability of other, preferred, inorganic $\mathrm{N}$ species (e.g. ammonia). $\mathrm{NO}_{3}{ }^{-}$removal occurs under anaerobic conditions either as dissimilatory $\mathrm{NO}_{3}{ }^{-}$ reduction to ammonium or as denitrification into $\mathrm{N}$ gas. Nitrifying biofilters can amount to $20 \%$ of the investment costs of a RAS (Eshchar et al. 2006), so reducing this cost or developing profitable alternatives is important on the way toward more economical systems. RAS technology is well advanced in Europe, already dominating production in a few countries (Badiola et al. 2012). In tropical countries, where the cost of land, energy and labor are lower, it is still in its infancy. However, with increasing scarcity of natural resources and coastal space and its application in broodstock development and larval rearing, its relevance is increasing in the developing tropics as well, and research is needed to meet future needs (Ranjan et al. 2019). Also, the implementation of IMTA is still hindered by various infrastructure, legislation and economic hurdles, and widespread adoption can only be achieved through site-specific targeted approaches and upscaling research and development beyond small tank or laboratory experiments (Chopin 2017, Kleitou et al. 2018). A focus on appropriate technology or 'low-tech' systems is an opportunity to support aquaculture adoption and 
success in the developing tropics (Heyman et al. 1989, Maucieri et al. 2019).

Tanzania is one of the main producers of seaweeds, and seaweed farming plays an important role in its economy (especially as an income opportunity for women) and has widely improved living standards (Eklöf et al. 2012, Msuya 2013). However, seaweed prices and associated income are volatile and strongly influenced by international markets (Bryceson 2002). Efforts have therefore been made by the government and a consortium of local and international partners to promote aquaculture activities and to diversify the aquaculture sector in terms of species produced (FAO 2017). Chanos chanos, commonly known as milkfish, are sufficiently tolerant to changing salinities and oxygen concentrations, making them a suitable candidate for the budding aquaculture sector of Zanzibar, but their cultivation is also prone to producing elevated nutrient levels and eutrophication (Mmochi et al. 2002, Holmer et al. 2003). The early stages of establishing milkfish production create an opportunity to investigate cultivation techniques with the aim to reduce environmental impacts (Rönnback et al. 2002, Troell et al. 2011).

This study provides a proof-of-concept of an IMTA RAS setup, integrating milkfish C. chanos, sea cucumber $H$. scabra and, for the first time, sea purslane $S$. portulacastrum in a tropical country. This experimental study aims to answer the following questions: (1) How does a RAS, integrating milkfish, sandfish and sea purslane, perform in terms of survival and biomass production? (2) Is it feasible to run the RAS with sea cucumber and halophyte tanks instead of conventional biofilters, and what is the individual fil- ter performance? (3) Do the sea cucumber and halophyte tanks improve the use of feed-derived $\mathrm{N}$ ?

\section{MATERIALS AND METHODS}

\subsection{Experimental setup}

The experiment was conducted over a period of $70 \mathrm{~d}$, from 7 December 2018 to 14 February 2019, at the Zanzibar Mariculture hatchery, Tanzania. Three replicates of a closed recirculation system were constructed, each consisting of a fiberglass tank for fish, sea cucumber and halophyte cultivation (Fig. 1). In the fish tanks, $10 \mathrm{~cm}$ diameter PVC pipes were connected to an overflow hole, $20 \mathrm{~cm}$ from the tank top edge, as well as to a drainage hole in the middle of the tank bottom that could be drained using a ball valve. The fish tanks were covered with $5 \mathrm{~mm}$ mesh to reduce stress to the animals. The tanks were filled with saline well water. Water temperature in the tanks ranged from $25.9-30.5^{\circ} \mathrm{C}$ with an average $( \pm \mathrm{SD})$ of $28.1 \pm 0.9^{\circ} \mathrm{C}$. Salinity ranged from $25.9-30.5$, with an average $( \pm \mathrm{SD})$ of $30.3 \pm 1.2$. The fish tanks were stocked with milkfish $(\mathrm{n}=9)$ of $124 \pm 29 \mathrm{~g}( \pm \mathrm{SD})$ and $\sim 20 \mathrm{~cm}$ length, resulting in a stocking density $( \pm \mathrm{SD})$ of $1657.3 \pm 163.6 \mathrm{~g} \mathrm{~m}^{-3}$. The sea cucumbers $(\mathrm{n}=10)$ had an average weight of $8.5 \pm$ $2.4 \mathrm{~g}$ and length of $5.6 \pm 0.7 \mathrm{~cm}$ at stocking, resulting in a density of $32.1 \pm 3.8 \mathrm{~g} \mathrm{~m}^{-2}$. The halophytes $(\mathrm{n}=70)$ weighed an average of $13.2 \pm 4.0 \mathrm{~g}$ and were planted at a density of $2271.6 \pm 30.8 \mathrm{~g} \mathrm{~m}^{-2}$. An acclimatization phase was not deemed necessary, as all organisms had been kept in similar environmental conditions at the hatchery before the experiment.

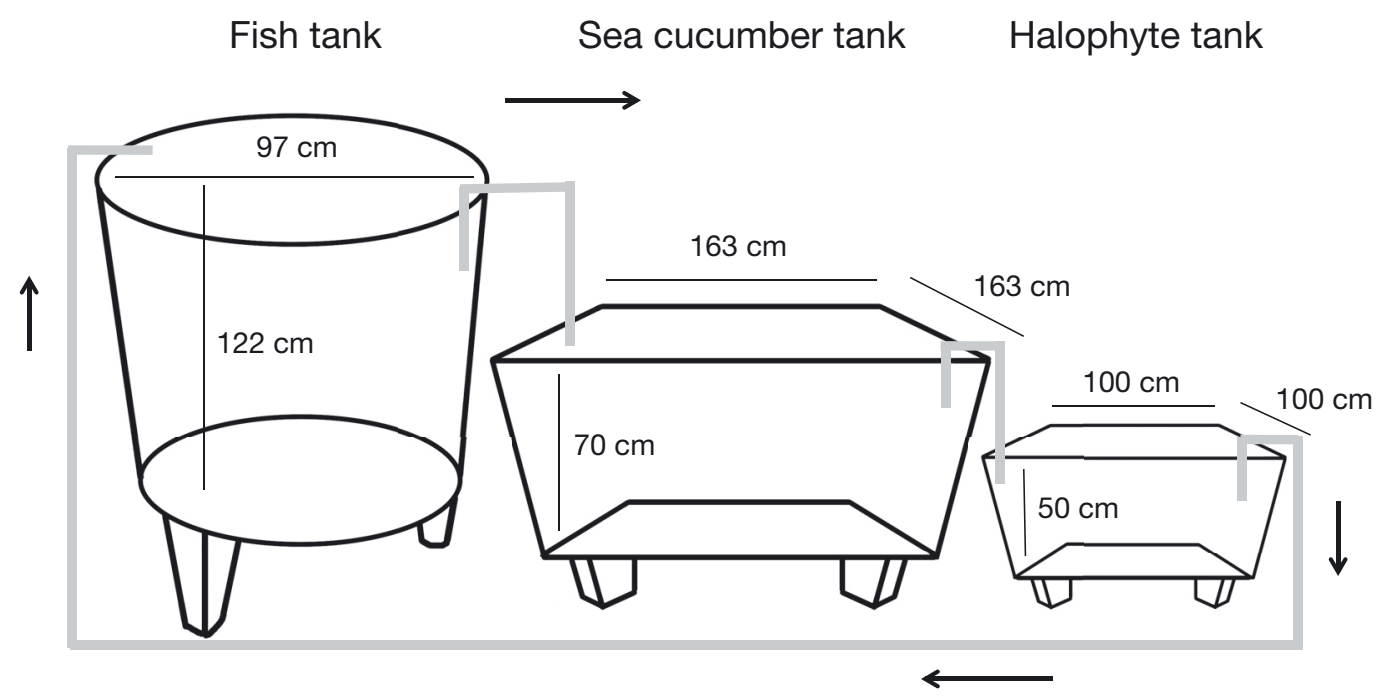

Fig. 1. Schematic set-up of the experimental recirculation aquaculture system (RAS). Grey lines: water pipes; black arrows: direction of water flow 
A simplified airlift system was constructed to allow oxic conditions to be maintained by water circulation through the sediment (Robinson et al. 2015). The system consisted of an outer frame of $1.25 \mathrm{~cm}$ high-pressure PVC pipes with 2 pipes crossing the tank bottom, $30 \mathrm{~cm}$ from the tank wall, and with holes every $15 \mathrm{~cm}$. The outer frame was connected to two $40 \mathrm{~cm}$ vertical pipes on each side, into which $2 \mathrm{~mm}$ diameter tubing pumped air in the bottom, causing water to be sucked up through the vertical tubes and creating water circulation through the sediment (Fig. 2). The bottom frame was covered in a $10 \mathrm{~cm}$ layer of gravel, covered with geotextile and a layer of carbonate sand sourced from the local beach. This type of tank design has been shown to prevent the formation of predominantly anoxic sediments (Robinson et al. 2015). The oxygenated sediment supports microbial communities that are more diverse, stable and have greater bioremediation potential of nitrogenous wastes than anoxic sediments (Robinson et al. 2016). The sea cucumber tank was filled with saline well water and treated with $100 \mathrm{ppm}$ chlorine for $3 \mathrm{~d}$ before stocking. The tanks were stocked on Day 0 of the experiment (Table 1). The halophytes were planted into $2 \mathrm{~cm}$ diameter holes cut into a $50 \times 80 \mathrm{~cm}$ piece of marine-grade plywood and held in place by $35 \mathrm{~cm}$ strips of geotextile wrapped around the stem right above the roots. Aeration in the fish and halophyte tanks was provided through tubing and airstones.

System design that is too costly and complex to maintain has been identified as a common reason for the failure of RAS operations (Badiola et al. 2012). The system studied here was built with this in mind and kept relatively simple. High-pressure PVC pipes (1.25 $\mathrm{cm}$ diameter) connected the tanks so that water flowed via syphon from the fish tank into the sea cucumber tanks and then into the halophyte tank. From the halophyte tank it was then pumped (Emperor 22000 submersible pump, Yi Hu Fish Farm

Table 1. Initial stocking (mean $\pm \mathrm{SD})$ of the tanks in the 3 RAS $(n=3)$

\begin{tabular}{|lrcrc|}
\hline Tank & $\begin{array}{c}\text { Stocking } \\
(\mathrm{n})\end{array}$ & $\begin{array}{c}\text { Stocking } \\
\text { density }\end{array}$ & $\begin{array}{c}\text { Total } \\
\text { biomass (g) }\end{array}$ & $\begin{array}{c}\text { Water } \\
\text { volume (l) }\end{array}$ \\
\hline Fish & $9 \pm 1$ & $1657.3 \pm 163.6 \mathrm{~g} \mathrm{~m}^{-3}$ & $1072 \pm 106$ & $647 \pm 13$ \\
Sea cucumbers & $10 \pm 0$ & $32.1 \pm 3.8 \mathrm{~g} \mathrm{~m}^{-2}$ & $85 \pm 10$ & $965 \pm 41$ \\
Halophytes & $70 \pm 0$ & $2271.6 \pm 30.8 \mathrm{~m}^{-2}$ & $909 \pm 12$ & $390 \pm 44$ \\
\hline
\end{tabular}

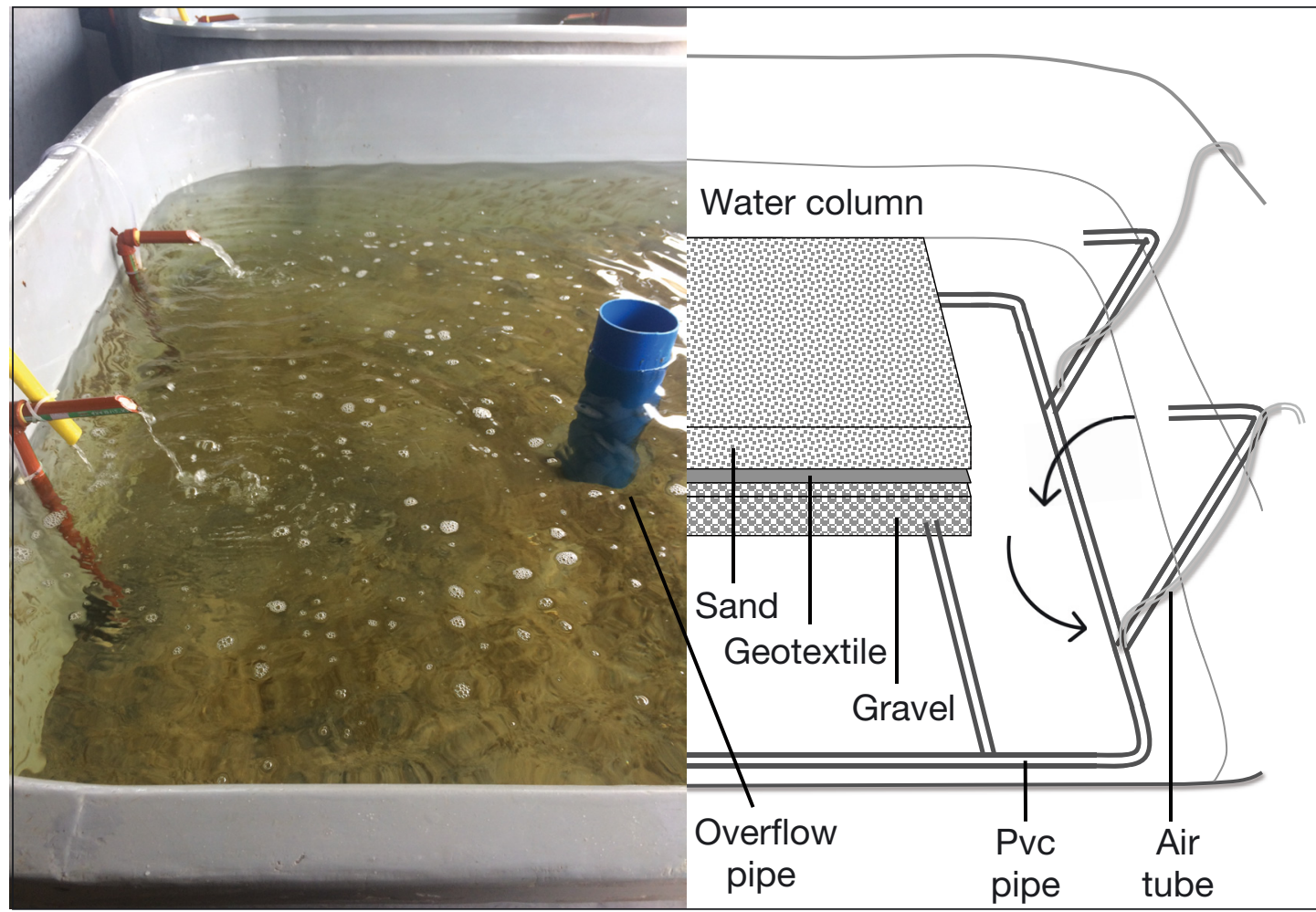

Fig. 2. Image and schematic of sea cucumber tank with airlift system. Arrows indicate the general direction of water flow down through the sediment and up through the airlift pipe 
Trading) back into the fish tank at a flow rate of $270 \mathrm{l} \mathrm{h}^{-1}$. The water was circulated continuously for the first $16 \mathrm{~d}$ of the experiment. For the remainder of the experimental period, circulation was interrupted every Friday at 16:00 $\mathrm{h}$ and resumed the following Monday at 10:00 h. This allowed us to determine the development of nutrient concentration in the fish, sea cucumber and halophyte tanks individually.

The fish were fed daily with commercial fish feed (Hill Pellet_Fish, Hill Animal Feeds \& Agrovet Supplies) at a rate of $4 \%$ body weight $\mathrm{d}^{-1}$. Once a week, saline well water was added to adjust for water losses from leakage and evaporation, and the salinity was adjusted by adding fresh water. Every Monday, Wednesday and Friday, settled sludge (fish feces and uneaten feed) from the bottom of the fish tank was flushed through the drainage pipe, filtered through a $80 \mu \mathrm{m}$ sieve, weighed and distributed in the sea cucumber tank after re-suspension in $500 \mathrm{ml}$ of tank water.

\subsection{Sampling and analysis}

The milkfish were weighed at the beginning and at the end of the experiment. The animals were sedated with clove oil (Priborsky \& Velisek 2018), wrapped in a wet cloth and weighed individually. Sea cucumber weight was assessed at stocking, on Day 28 and at the end of the experiment. Before weighing, the sea cucumbers were suspended in mesh bags for $24 \mathrm{~h}$ to allow for the gut to be emptied, then placed on tissue paper for $1 \mathrm{~min}$, measured, photographed and weighed (Sewell \& Bergquist 1990). Weight data were used to calculate absolute growth, specific growth rate (SGR) and food conversion ratio (FCR) for milkfish and absolute growth and SGR for sea cucumbers.

Before stocking the halophytes, each plant was weighed individually. At the end of the experiment, entanglements of the grown plants made harvesting of individuals difficult and only 10 plants from each tank were sampled to determine the individual biomass as well as above ground (stem and leaves) and below ground (roots) biomass. The rest of the plants were weighed cumulatively. Weight data were used to calculate absolute growth and SGR. Three plants from each tank were dried at $60^{\circ} \mathrm{C}$, homogenized and ground for $\mathrm{C}: \mathrm{N}$ content. All organisms were weighed on a Kern PCB 6000-1 Precision Scale (Kern \& Sohn).

Every Monday before the system was started and every Friday after stopping the water circulation, water was sampled for analysis of $\mathrm{NO}_{2}^{-}-\mathrm{N}, \mathrm{NO}_{3}^{-}-\mathrm{N}$, total ammonia $\mathrm{N}$ (TAN) and $\mathrm{PO}_{4}{ }^{-}$-P. Water samples
(20 ml) were taken with a syringe, filtered through $0.45 \mu \mathrm{m}$ syringe filters into acid-washed $20 \mathrm{ml}$ plastic bottles and stored frozen. Spectrophotometric analysis of dissolved inorganic nutrients was carried out following the procedures of Strickland \& Parsons (1972) with an Infinite 200 PRO microplate reader (TECAN). Dissolved inorganic N (DIN) was determined as the sum of $\mathrm{NO}_{2}^{-}-\mathrm{N}, \mathrm{NO}_{3}{ }^{-}-\mathrm{N}$ and TAN. On sampling occasions, we also determined the volume of water in each tank by measuring water depth with a $100 \mathrm{~cm}$ ruler. Every Monday, Wednesday and Friday, we measured $\mathrm{pH}$, salinity, temperature and dissolved oxygen with a multiparameter probe (WTW).

Samples of the surface sediment in the sea cucumber tanks for the determination of $\mathrm{N}$ content were taken in $2 \mathrm{wk}$ intervals. A $20 \mathrm{ml}$ cut-off syringe was used as a corer (surface area of $3.14 \mathrm{~cm}^{2}$ ), taking 5 samples, $2 \mathrm{~cm}$ deep into the sediment, which were then pooled for each tank, dried and analyzed.

During the last week of the experiment, water from all tanks was sampled on 2 consecutive Mondays before starting water circulation, as well as on the Wednesday and Friday in between, and filtered for total suspended solids (TSS). From each tank, $1500 \mathrm{ml}$ of water were sampled and 250-1500 ml were filtered over a glass microfiber filter with particle retention of $0.7 \mu \mathrm{m}$ (VWR International). Filters were then dried and weighed. At the end of the experiment, organic matter and algae on the tank walls and bottom were collected, weighed and measured for $C: N$ content. All samples for $C: N$ content were analyzed using a Euro EA-CHNSO Elemental Analyzer (HEKAtech).

Basic data analysis and visualization was performed in Microsoft Excel and R version 3.6.2 (R Core Team 2019). Data are presented as mean \pm SD or as individual data points.

\section{RESULTS}

\subsection{Growth and survival}

The organisms in all 3 systems increased in biomass at a SGR above $1 \% \mathrm{~d}^{-1}$ for all species (Table 2 ). Survival was $100 \%$.

\subsection{Water quality}

The $\mathrm{pH}$ ranged from 7.7-8.2, with an average of 7.9 \pm 0.1 ; dissolved oxygen ranged from $5.5-8.9 \mathrm{mg} \mathrm{l}^{-1}$, averaging $7.3 \pm 0.7$. TAN concentrations in the sys- 
Table 2. Growth (mean $\pm \mathrm{SD}$ ) of the organisms in the RAS $(n=3)$. SGR: specific growth rate; FCR: food conversion ratio; (-) not applicable

\begin{tabular}{|lcccc|}
\hline Tank & $\begin{array}{c}\text { Absolute growth } \\
\left(\mathrm{g} \mathrm{d}^{-1}\right)\end{array}$ & $\begin{array}{c}\text { SGR } \\
\left(\% \mathrm{~d}^{-1}\right)\end{array}$ & FCR & $\begin{array}{c}\text { Final density } \\
\left(\mathrm{g} \mathrm{m}^{-2}\right)\end{array}$ \\
\hline Fish & $1.9 \pm 0.2$ & $1.1 \pm 0.1$ & $2.3 \pm 0.2$ & - \\
Sea cucumbers & $1.2 \pm 1.1$ & $1.1 \pm 0.7$ & - & $\begin{array}{c}67 \pm 25 \\
\text { Halophytes }\end{array}$ \\
\hline
\end{tabular}

tems peaked on Day 4 in all tanks and subsequently decreased. They remained low in the sea cucumber and halophyte tanks, while concentrations in the fish tanks were higher. $\mathrm{NO}_{2}{ }^{-}$concentrations were highest within the first $29 \mathrm{~d}$, after which they remained low in over time in all tanks, in the case of $\mathrm{NO}_{3}{ }^{-}$up to a plateau around $17 \mathrm{mg} \mathrm{N}^{-1}$ (Fig. 3).

During the time periods when water circulation was turned off and water remained in the same tank, concentrations of all inorganic $\mathrm{N}$ species as well as $\mathrm{PO}_{4}{ }^{-}$ increased in the fish tanks. In the sea cucumber tanks, concentrations of $\mathrm{NO}_{3}{ }^{-}$and $\mathrm{PO}_{4}{ }^{-}$increased as well, while $\mathrm{NO}_{2}{ }^{-}$and TAN decreased. In the water that remained in the halophyte tanks, concentrations of all tanks. $\mathrm{NO}_{3}{ }^{-}$and $\mathrm{PO}_{4}{ }^{-}$concentrations increased

$\mathrm{NO}_{2}^{-}$, TAN and $\mathrm{PO}_{4}^{-}$did not change, but $\mathrm{NO}_{3}^{-}$concentrations decreased (Table S1 in the Supplement at www. int-res.com/articles/suppl/q012p471_ supp.pdf). An average of $3.5 \pm 0.2 \mathrm{~g}$ of DIN developed in the fish tanks (Fig. 4). During this time, the total DIN in the sea cucumber tanks increased by $0.9 \pm$ $0.7 \mathrm{~g}$. Only the halophyte tanks showed a net decrease of $0.7 \pm 0.1 \mathrm{~g}$ DIN. During the $7 \mathrm{wk}$ of this sampling regime, DIN in the halophyte tanks was reduced by a total of $4.9 \pm 1 \mathrm{~g} \mathrm{~N}$.

Concentrations of TSS visibly increased in the fish tanks when the system was turned off and decreased when the water was circulated. Sampling during the last week of the experiment revealed an average decrease of $75.7 \pm 0.8 \%$ in the fish tanks. During the same time period, overall concentrations in the sea cucumber and halophyte tanks were much lower and more variable, decreasing by $33.3 \pm 39.9 \%$ in the sea cucumber tanks and increasing by $12.3 \pm 45.1 \%$ in the halophyte tanks (Fig. 5).

$\mathrm{N}$ content in the surface sediments of the sea cucumber tanks was very low overall, but increased over the course of the experiment (Fig. 6).
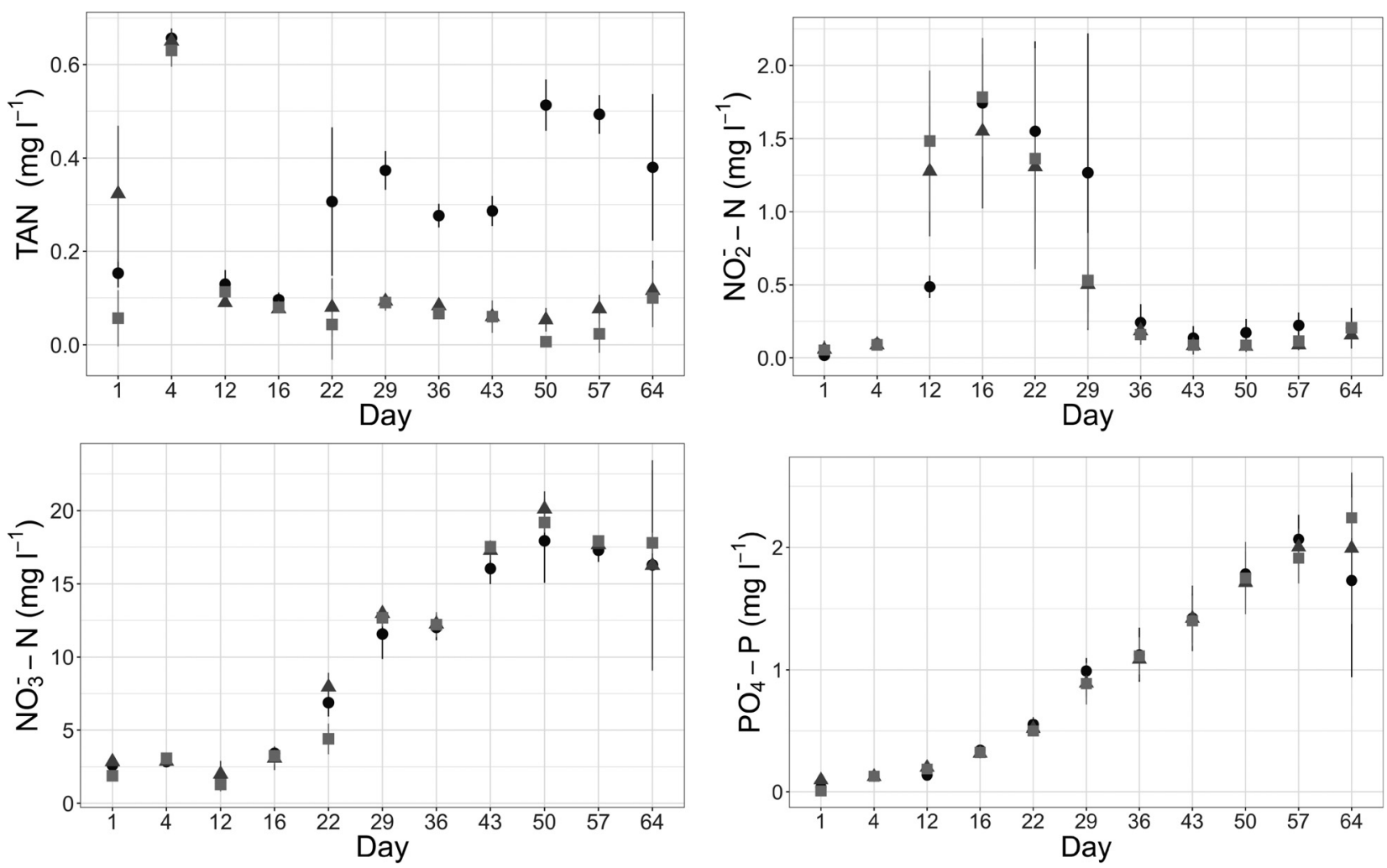

Fig. 3. Mean $( \pm \mathrm{SD})$ concentrations of dissolved nutrients measured weekly in the tanks of the RAS systems ( $\mathrm{n}=3$ ) over the course of the experiment. Black circles: Fish tanks; dark grey triangles: sea cucumber tanks; light grey squares: halophyte tanks; TAN: total ammonia $\mathrm{N}$ 

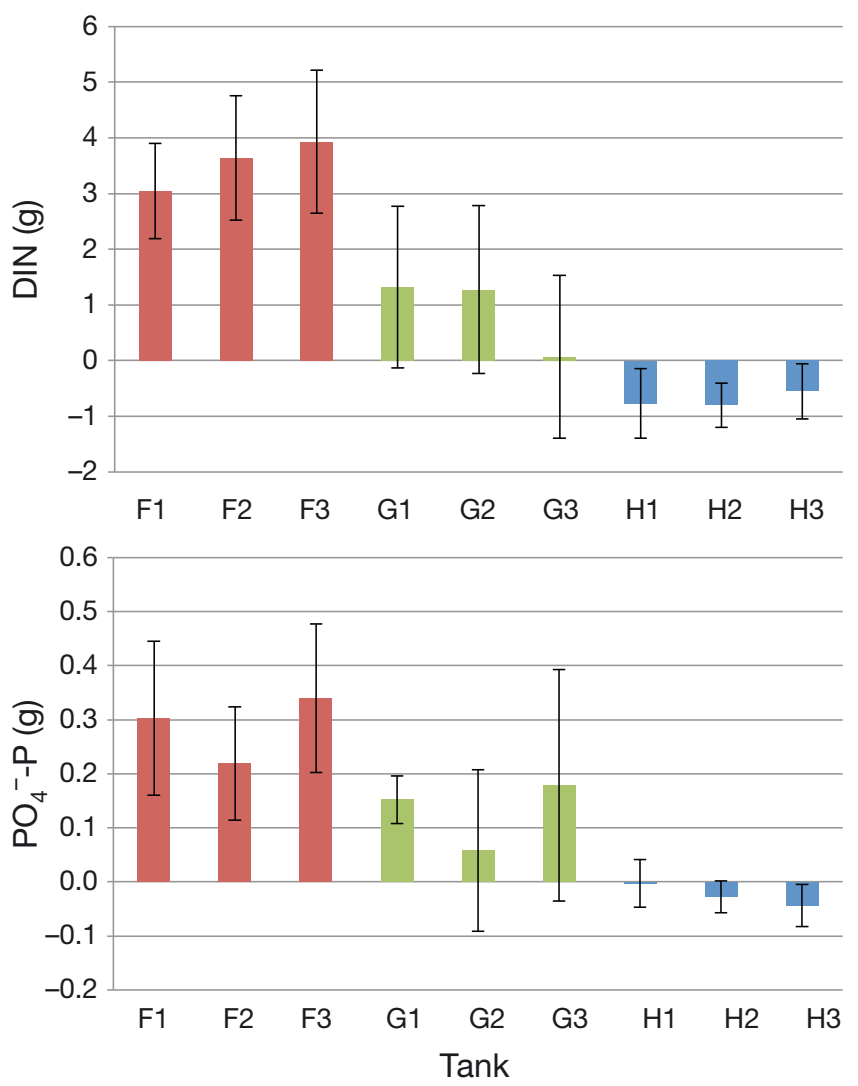

Fig. 4. Average $( \pm \mathrm{SD})$ change in total dissolved inorganic nitrogen (DIN) and $\mathrm{PO}_{4}-\mathrm{P}$ in the individual tanks (F: fish; G: sea cucumber; $\mathrm{H}$ : halophyte) of the RAS $(\mathrm{n}=3)$, after periods of interrupted water circulation during the $70 \mathrm{~d}$ experiment

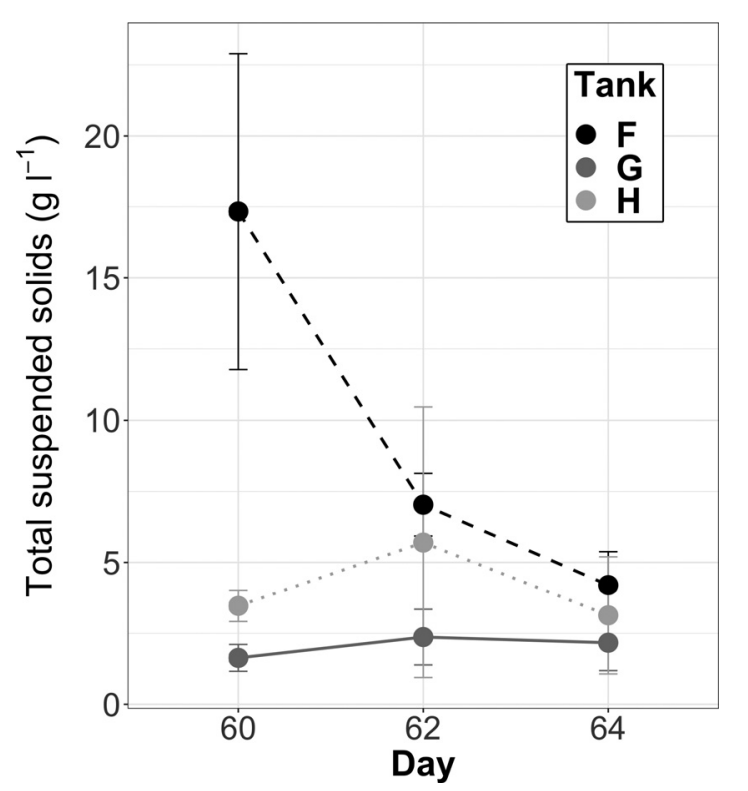

Fig. 5. Mean ( $\pm \mathrm{SD})$ total suspended solids in the fish $(\mathrm{F})$, sea cucumber $(\mathrm{G})$ and halophyte $(\mathrm{H})$ tanks of the RAS during the last week of the experiment

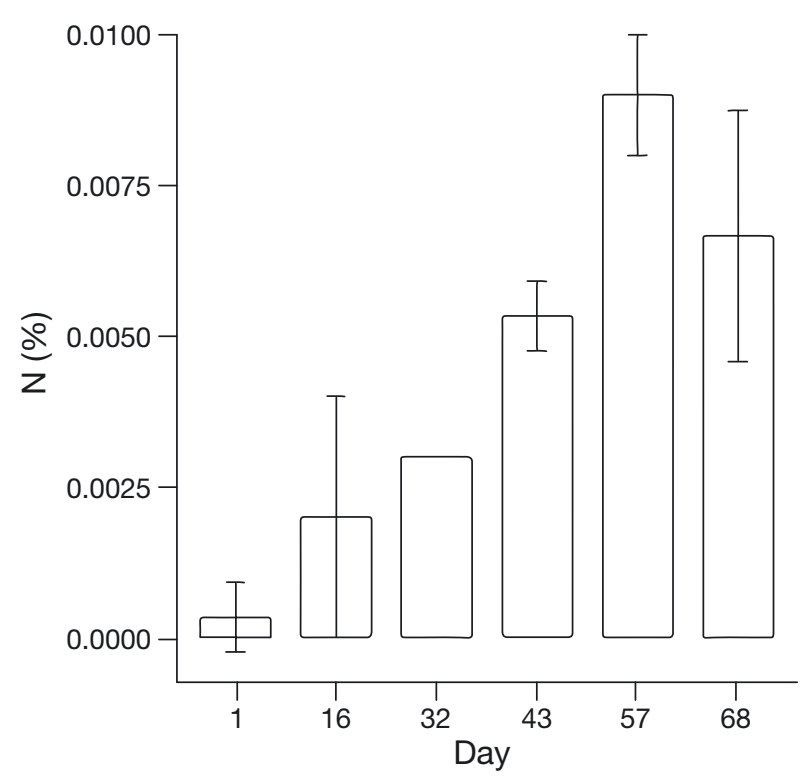

Fig. 6. Mean $( \pm \mathrm{SD})$ nitrogen $(\mathrm{N})$ content (\% of dry weight) in the surface sediment of the sea cucumber tanks in the RAS $(\mathrm{n}=3)$

\section{3. $\mathbf{N}$ budget}

Over the course of the experiment, each RAS received an input of $132 \mathrm{~g} \mathrm{~N}$ via the fish feed. The constructed budget accounted for an average of $89.1 \pm 8.7 \mathrm{~g}$ and $69.4 \pm 5.1 \%$ of the $\mathrm{N}$ input (Table 3 ); $48.1 \pm 3.5 \mathrm{~g}$ and $36.4 \pm 2.6 \%$ of $\mathrm{N}$ were in the form of usable biomass of fish, sea cucumbers or halophytes (Fig. 7).

\section{DISCUSSION}

\subsection{Performance of the RAS in terms of biomass production}

Overall, the IMTA RAS performed well, as survival was $100 \%$ of all organisms and growth was recorded across all system components. All milkfish increased in weight and were apparently healthy. The observed average individual growth of $1.9 \mathrm{~g} \mathrm{fish}^{-1} \mathrm{~d}^{-1}$ and the average SGR of $1.1 \% \mathrm{~d}^{-1}$ was on the lower end, but comparable to other studies (Guanzon et al. 2004, Jana et al. 2006). The average FCR of 2.3 was high compared to milkfish in pond aquaculture (Sumagaysay-Chavoso \& San Diego-McGlone 2003). At $1.7 \mathrm{~kg} \mathrm{~m}^{-3}$, the initial stocking density was much lower than in intensive aquaculture and more comparable to the maintenance of broodstock (Marte 1988, Ranjan et al. 2019). The study had, however, 
Table 3. Average $( \pm \mathrm{SD})$ total input of feed (into fish tanks) and sludge (into sea cucumber tanks) and biomass production as wet weight (dry weight for algae) $(\mathrm{g})$, nitrogen $(\mathrm{g} \mathrm{N})$ and $\%$ of feed input $(\% \mathrm{~N})$ of the RAS $(\mathrm{n}=3)$ at the end of the $70 \mathrm{~d}$ experiment. (-) not applicable

\begin{tabular}{|c|c|c|c|c|c|c|c|c|}
\hline Tank & & $\begin{array}{c}\text { Input } \\
\text { (feed/sludge) }\end{array}$ & $\begin{array}{l}\text { Biomass } \\
\text { produced }\end{array}$ & $\begin{array}{c}\text { Dissolved } \\
\mathrm{N}\end{array}$ & $\begin{array}{l}\text { Sediment } \\
\mathrm{N}\end{array}$ & Algae & $\begin{array}{l}\text { Organic } \\
\text { matter }\end{array}$ & $\begin{array}{c}\text { Total N } \\
\text { accounted for }\end{array}$ \\
\hline Fish & $\begin{array}{c}\mathrm{g} \\
\mathrm{gN} \\
\% \mathrm{~N}\end{array}$ & $\begin{array}{r}2620.0 \pm 0.0 \\
132.1 \pm 0.0 \\
100 \pm 0.0\end{array}$ & $\begin{array}{c}1147.3 \pm 78.2 \\
44.3 \pm 3.0 \\
33.6 \pm 2.3\end{array}$ & $\begin{array}{c}11.4 \pm 4.6 \\
- \\
8.66 \pm 3.5\end{array}$ & $\begin{array}{l}- \\
- \\
-\end{array}$ & $\begin{array}{l}- \\
- \\
-\end{array}$ & $\begin{array}{l}- \\
- \\
-\end{array}$ & $\begin{array}{c}1147.4 \pm 78.2 \\
55.8 \pm 7.6 \\
42.2 \pm 5.7\end{array}$ \\
\hline Sea cucumber & $\begin{array}{c}g \\
g \mathrm{~N} \\
\% \mathrm{~N}\end{array}$ & $\begin{array}{r}814.3 \pm 1.0 \\
1.0 \pm 0.3 \\
0.8 \pm 0.2\end{array}$ & $\begin{array}{c}92.3 \pm 68.3 \\
0.6 \pm 0.4 \\
0.5 \pm 0.3\end{array}$ & $\begin{array}{c}16.24 \pm 6.9 \\
- \\
12.3 \pm 5.2\end{array}$ & $\begin{array}{c}- \\
6.5 \pm 2.0 \\
4.9 \pm 1.5\end{array}$ & $\begin{array}{l}- \\
- \\
-\end{array}$ & $\begin{array}{c}28.8 \pm 20.3 \\
0.1 \pm 0.1 \\
0.1 \pm 0.1\end{array}$ & $\begin{aligned} 935.4 & \pm 170.4 \\
108.9 & \pm 53.2 \\
18.5 & \pm 3.9\end{aligned}$ \\
\hline Halophyte & $\begin{array}{c}\mathrm{g} \\
\mathrm{g} \mathrm{N} \\
\% \mathrm{~N}\end{array}$ & $\begin{array}{l}- \\
- \\
-\end{array}$ & $\begin{array}{c}1261.0 \pm 95.1 \\
3.1 \pm 0.2 \\
2.4 \pm 0.2\end{array}$ & $\begin{array}{c}6.2 \pm 0.9 \\
- \\
4.7 \pm 0.6\end{array}$ & $\begin{array}{l}- \\
- \\
-\end{array}$ & $\begin{array}{c}51.7 \pm 39.7 \\
1.6 \pm 1.2 \\
1.2 \pm 0.9\end{array}$ & $\begin{aligned} 226.0 & \pm 144.6 \\
0.5 & \pm 0.2 \\
0.4 & \pm 0.1\end{aligned}$ & $\begin{aligned}- & \\
11.4 & \pm 1.8 \\
8.6 & \pm 1.3\end{aligned}$ \\
\hline
\end{tabular}

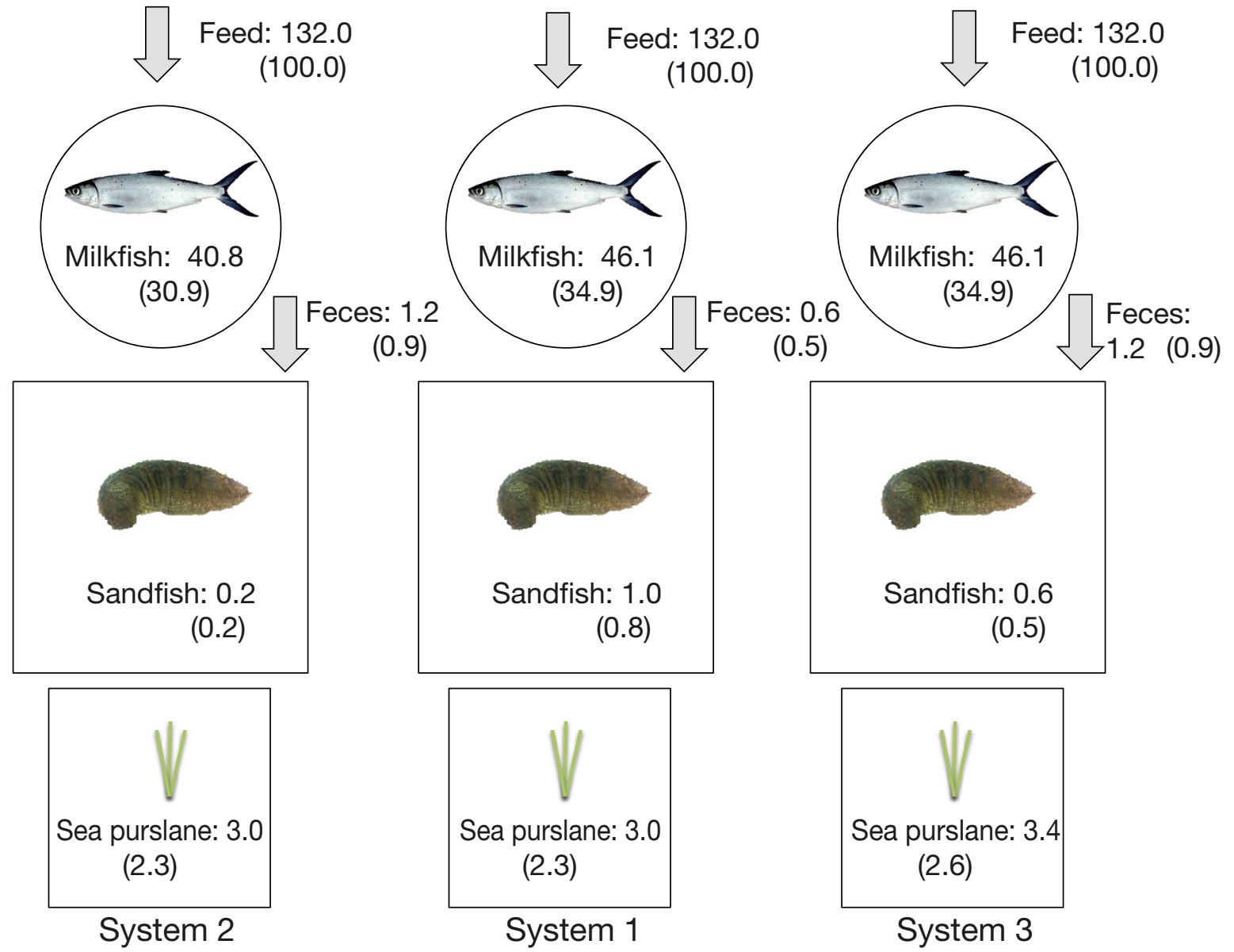

Fig. 7. Conceptual representation of the 3 experimental RAS, each including a milkfish tank, sea cucumber tank and hydroponic sea purslane tank. Numbers indicate the $\mathrm{N}$ content $(\mathrm{g})$ of the different compartments, with the corresponding \% $\mathrm{N}$ relative to the input (feed) in parentheses

been designed according to semi-intensive aquaculture practices on Zanzibar with conservative stocking densities and low-performance equipment. Given that water quality remained acceptable throughout the experiment, stocking density could be increased and a higher feeding rate could be divided between 2 or more daily feedings in order to achieve better growth and allow for the results to act as better reference values for aquaculture production (Sumagaysay 1998). 
Despite similar initial size, individual growth rates of the sandfish were highly variable. This is to be expected as sea cucumber growth often varies and is determined by a number of different factors, including individual genetics (Qiu et al. 2014, Dumalan et al. 2019). Absolute growth and SGR observed in this experiment were comparable to that of Holothuria scabra during sea ranching studies (Namukose et al. 2016), feeding experiments on organic waste from shrimp farming (Watanabe et al. 2012, Hochard et al. 2016) and grow-out trials underneath milkfish net pens (Dumalan et al. 2019). As mortality can be high when small sandfish are transferred to grow-out pens, keeping juveniles at hatcheries until a size of >50 g improves survival (Purcell \& Simutoga 2008, Dumalan et al. 2019).

The yield of sea purslane in the RAS was lower than the biomass production of $0.53 \mathrm{~kg} \mathrm{~m}^{-2}$ found in aquaponics integrated with platy fish Xiphophorus sp. (Boxman et al. 2017), and the relative growth rate was comparatively low (Slama et al. 2017). Concentrations of $\mathrm{NO}_{3}{ }^{-}$and $\mathrm{PO}_{4}{ }^{-}$in the halophyte tanks were similar to a RAS experiment testing 3 species of halophytes in hydroponic cultivation in the waste water of European seabass Dicentrarchus labrax (Waller et al. 2015). The authors of that study measured concentrations of 19-21 $\mathrm{mg} \mathrm{N}^{-1}$ and $3 \mathrm{mg} \mathrm{P}^{-1}$, considering low nutrient availability, compared to typical nutrient solution in hydroponic culture. Higher nutrient concentration in the halophyte tanks would therefore be favorable for the production of sea purslane biomass.

\subsection{Feasibility to run the RAS without conventional biofilters}

Infrastructure restrictions did not allow testing the filter performance of the sea cucumber and halophyte tanks compared to control treatments. While single systems are sometimes evaluated in aquaculture research to study feasibility (Waller et al. 2015, Ranjan et al. 2019, Yogev \& Gross 2019), running the experiment in triplicate allowed us to also show performance variability.

The concentrations of dissolved inorganic nutrients remained acceptable for aquaculture production and organism health throughout the duration of the experiment. After an initial increase during the first week, TAN levels in the sea cucumber and sea purslane tanks remained low. During continuous water circulation, concentrations in the fish tanks were below $1 \mathrm{mg} \mathrm{l}^{-1}$ TAN-N, and even after increases over the weekend, concentrations were comparatively low (Carton-Kawagoshi et al. 2014). While some ammonia oxidizing microbes might have been present in the sediment of the sea cucumber tank despite the initial chlorine treatment, it usually takes weeks to months for a bacterial community to establish (Gutierrez-Wing \& Malone 2006, Keuter et al. 2017). The quick decreases in TAN concentrations may also be attributed to direct assimilation of ammonium by halophytes and microbes (Quintã et al. 2015, Klawonn et al. 2019). $\mathrm{NO}_{2}{ }^{-}$can be toxic to fish and is thus of great concern in aquaculture, but even during peak concentrations, levels in this experiment remained far below lethal levels (around $675 \mathrm{mg} \mathrm{l}^{-1} \mathrm{NO}_{2}^{-}-\mathrm{N}$ ) (Almendras 1987). The highest $\mathrm{NO}_{2}{ }^{-}$concentrations were measured on Day 16 and stayed low for the remainder of the experiment. Decreases in ammonia concentrations followed by a $\mathrm{NO}_{2}{ }^{-}$peak and subsequently increasing $\mathrm{NO}_{3}{ }^{-}$concentrations are indicative of the 2-step aerobic nitrification process of biological oxidation of ammonia to $\mathrm{NO}_{2}{ }^{-}$, and $\mathrm{NO}_{2}{ }^{-}$to $\mathrm{NO}_{3}{ }^{-}$, and provide evidence of nitrification activity (Keuter et al. 2017, Brailo et al. 2019). This is likely to have occurred in the oxygenated sand substrate of the sea cucumber tanks, which would have provided an ideal habitat for a diverse and stable bacterial community of facultative aerobes with good bioremediation potential (Robinson et al. 2016)

DIN was mostly present in the form of $\mathrm{NO}_{3}{ }^{-}$, which increased over the course of the experiment. Such a build-up is typical for zero-exchange RAS without denitrifying filters (DeLong \& Losordo 2012, Keuter et al. 2017). Although fluctuating nutrient concentrations can impact bacterial communities (Blancheton et al. 2013), interrupted water circulation apparently did not prevent an adequate biofilter performance in the sea cucumber and halophyte tanks in this experiment. Furthermore, the time periods without water exchange provided an opportunity to examine the development of nutrient concentrations in the individual tanks. The increase in concentration of all measured dissolved inorganic nutrients plausibly identified the fish tanks as the main source of $\mathrm{N}$ and $\mathrm{P}$ in the system. The decrease of TAN and $\mathrm{NO}_{2}{ }^{-}$with an increase of $\mathrm{NO}_{3}{ }^{-}$in the sea cucumber tanks further identifies it as the main site of nitrification. When the water remained in the halophyte tanks, concentrations of $\mathrm{NO}_{2}{ }^{-}$, TAN and $\mathrm{PO}_{4}{ }^{-}$remained the same, so nitrification or $\mathrm{PO}_{4}{ }^{-}$uptake are unlikely to have occurred. $\mathrm{NO}_{3}{ }^{-}$concentrations, however, decreased, indicating that the tanks acted as a net sink of $\mathrm{NO}_{3}{ }^{-}$, unlike the fish and sea cucumber tanks, sug- 
gesting that the hydroponic cultivation of Sesuvium portulacastrum did prevent higher $\mathrm{NO}_{3}{ }^{-}$concentrations. The mean decrease of $4.9 \mathrm{~g} \mathrm{~N}$ was well accounted for by the $\mathrm{N}$ measured in the biomass of sea purslane, as well as filamentous green algae and other organic matter recovered from the halophyte tanks, which averaged a total of $5.2 \mathrm{~g} \mathrm{~N}$. Considering that some $\mathrm{N}$ was taken up during the first weeks of the experiment as well as the constant oxic conditions in the water column of the halophyte tanks, it can be assumed that the mechanism of $\mathrm{N}$ removal was due to assimilation, not denitrification (van Rijn et al. 2006). Denitrification can be achieved in settling basins of RAS (Gelfand et al. 2003), and a longer experimental period is recommended to investigate if it can be observed in this system as well. $\mathrm{NO}_{3}{ }^{-}$concentrations in the halophyte tanks both increased and decreased at times. Such fluctuations have been observed in hydroponic cultivation of halophytes (Waller et al. 2015, Boxman et al. 2017) and can be caused by mineralization of particulate organic matter (Hargreaves 1998).

$\mathrm{PO}_{4}{ }^{-}$decreased in both the halophyte tanks, as well as in the sea cucumber tanks to some extent, but concentrations showed a steady increase in the whole system. $\mathrm{PO}_{4}{ }^{-}$is not directly toxic to fish, but because it is usually limited in the environment, higher concentrations can cause harmful algal blooms (Kim et al. 2013). Improved removal of feed-derived $\mathrm{PO}_{4}{ }^{-}$ would therefore be desirable and could be achieved through the use of steel slag or limestone (Naylor et al. 2003).

TSS removal by constructed wetlands has been summarized by van der Gaag et al. (2010), who found a decrease of $67 \%$, leaving the performance of this IMTA system relatively high with an average decrease of $76 \%$ of TSS in the fish tanks over the course of the $5 \mathrm{~d}$ sampled. As suspended solids can cause clogging of the system, their removal is a requirement in integrated (aquaponic) systems (Wongkiew et al. 2017). This experiment suggests that the sea cucumber tanks serve well as settling basins without the need for further solids removal.

\subsection{Use of feed-derived $\mathbf{N}$ in the sea cucumber and halophyte tanks}

The RAS showed good recovery of feed-derived $\mathrm{N}$ in the form of fish biomass, which accounted for the majority of $\mathrm{N}$ at approximately $34 \%$ (Zhong et al. 2011, Poli et al. 2019). The amount of $\mathrm{N}$ that was collected in the form of sludge from the fish tanks was small considering that the sedimentation rate in milkfish aquaculture has been estimated to be as high as $60 \%$ of feed-derived N (Holmer \& Fortes 2002, Sumagaysay-Chavoso 2003). Taking into account the decrease in suspended solids from the fish to the sea cucumber tanks as well as the increase in sediment $\mathrm{N}$ content over time, it is likely that a considerable fraction of particulate matter was not collected manually, but remained suspended in the water column and settled into the sea cucumber tank. The percentage of $\mathrm{N}$ that was subsequently recovered as sea cucumber biomass was higher than the decrease of particle load by $0.73 \%$ previously determined for this species (Chary et al. 2020). A box model on the integration of $H$. scabra under milkfish cages estimated that $6.4 \%$ of particulate $\mathrm{N}$ could be recovered by the sea cucumbers, but the authors recognized that such recovery would require farming the sea cucumbers at densities much higher than has been found supportive of their growth (Watanabe et al. 2015). Good growth of $H$. scabra has been found up to densities of $250 \mathrm{~g} \mathrm{~m}^{-2}$, suggesting that stocking in this experiment could have been increased threefold to facilitate better $\mathrm{N}$ recovery in sea cucumber biomass (Purcell \& Simutoga 2008, Hochard et al. 2016). Biomass production in this study remained small, but the role of sea cucumbers in this IMTA RAS was rather as a valuable aquaculture organism to be cultivated on sand substrate, which in turn provides a medium for nitrifying bacterial communities (Zamora et al. 2018).

The constructed $\mathrm{N}$ budget accounted for approximately $69 \%$ of the feed-derived $\mathrm{N}$, which is high compared to other studies (Gross et al. 2000, Wang et al. 2015). After fish biomass, the second largest portion of $\mathrm{N}$ was found as DIN in the water of the different tanks. Recovery of $\mathrm{N}$ as halophyte biomass in this study was similar to the recovery of N in Salicornia in a wetland filter (Shpigel et al. 2013) and Sarcocornia ambigua in an IMTA with fish and shrimp (Poli et al. 2019). Higher rates have been achieved with the hydroponic cultivation of $S$. ambigua in hydroponic cultivation with shrimp (Pinheiro et al. 2017), which improved $\mathrm{N}$ use by an additional $6.4 \%$ and produced $2 \mathrm{~kg}$ of halophytes for $1 \mathrm{~kg}$ of shrimp, resulting in the recommendation to further increase the plant biomass relative to the biomass of fed animals. This study had a plant to fish biomass ratio of approximately 1:1. Given the changes in DIN concentrations in the fish and halophyte tanks, it would be recommended to increase this ratio to 5:1.

Future experiments studying the predominant $\mathrm{N}$ transformation processes and functional groups of 
bacteria using quantitative PCR and tracing $\mathrm{N}$ assimilation in detritivores and plants through stable isotope or fatty acid analysis could shed more light on the performance of low-tech integrated RAS.

\section{CONCLUSIONS}

This study showed the viability of a simple and lowcost RAS system, integrating valuable tropical species of 3 different trophic levels. For the first time, sea cucumbers and halophytes were combined, with these units replacing a separate biofilter. The system produced additional biomass while maintaining good water quality, and the overall low levels of dissolved inorganic nutrients and accumulated solid waste suggest that higher fish biomass could have been applied and maintained for a longer time period. Furthermore, higher sea cucumber stocking density and increased plant biomass would be recommended to improve recovery of both particulate and dissolved $\mathrm{N}$ and prevent accumulation in the system. The system operated without producing solid waste or discharging polluted water and optimized the use of water and space. This kind of sustainable aquaculture model has the potential to provide food security and income, and the simple system used here also allows for application in developing coastal communities.

Acknowledgements. The authors thank Dr. Aviti Mmochi and Dr. Flower Msuya for their support in logistical and organizational matters, Joyce John for great assistance in system maintenance and sampling, Mtumwa for facilitating sample preparation as well as the staff of the Zanzibar Mariculture hatchery for their invaluable support throughout the experiment. P.S. was supported by a grant of the German Academic Exchange Service (Deutscher Akademischer Austauschdienst, DAAD), grant program 57381316.

\section{LITERATURE CITED}

Ahmed N, Glaser M (2016) Can 'integrated multi-trophic aquaculture (IMTA)' adapt to climate change in coastal Bangladesh? Ocean Coast Manage 132:120-131

Almendras J (1987) Acute nitrite toxicity and methemoglobinemia in juvenile milkfish (Chanos chanos Forsskal). Aquaculture 61:33-40

Badiola M, Mendiola D, Bostock J (2012) Recirculating aquaculture systems (RAS) analysis: main issues on management and future challenges. Aquacult Eng 51:26-35

Blancheton JP, Attramadal KJK, Michaud L, d'Orbcastel ER, Vadstein O (2013) Insight into bacterial population in aquaculture systems and its implication. Aquacult Eng 53:30-39

Boxman SE, Nystrom M, Capodice JC, Ergas SJ, Main KL, Trotz MA (2017) Effect of support medium, hydraulic loading rate and plant density on water quality and growth of halophytes in marine aquaponic systems. Aquacult Res 48:2463-2477

Brailo M, Schreier HJ, McDonald R, Maršić-Lučić J, Gavrilović A, Pećarević M, Jug-Dujaković J (2019) Bacterial community analysis of marine recirculating aquaculture system bioreactors for complete nitrogen removal established from a commercial inoculum. Aquaculture 503: 198-206

Bryceson I (2002) Coastal aquaculture developments in Tanzania: sustainable and non-sustainable experiences. Western Indian Ocean J Mar Sci 1:1-10

* Buhmann A, Papenbrock J (2013) Biofiltering of aquaculture effluents by halophytic plants: basic principles, current uses and future perspectives. Environ Exp Bot 92: 122-133

* Cardoch L, Day JW, Rybczyk JM, Kemp GP (2000) An economic analysis of using wetlands for treatment of shrimp processing wastewater - a case study in Dulac, LA. Ecol Econ 33:93-101

Carton-Kawagoshi RJ, Elle BJ, Corre V, Satoh S, Notoya M, Fujita D (2014) Low water exchange Gracilariopsis bailiniae Zhang \& B.M. Xia culture in intensive milkfish culture effluents: effects of seaweed density on seaweed production and effluent treatment. Aquacult Int 22: 573-584

* Chary K, Aubin J, Sadoul B, Fiandrino A, Covès D, Callier MD (2020) Integrated multi-trophic aquaculture of red drum (Sciaenops ocellatus) and sea cucumber (Holothuria scabra): assessing bioremediation and life-cycle impacts. Aquaculture 516:734621

Chopin T (2017) Challenges of moving integrated multitrophic aquaculture along the R\&D and commercialization continuum in the western world. J Ocean Technol 12:34-47

Chopin T, Yarish C, Sharp G (2007) Beyond the monospecific approach to animal aquaculture - the light of integrated multi-trophic aquaculture. In: Bert TM (ed) Ecological and genetic implications of aquaculture activities. Methods and technologies in fish biology and fisheries, Vol 6. Springer, Dordrecht, p 447-458

* Custódio M, Villasante S, Cremades J, Calado R, Lillebø AI (2017) Unravelling the potential of halophytes for marine integrated multi-trophic aquaculture (IMTA) - a perspective on performance, opportunities and challenges. Aquacult Environ Interact 9:445-460

DeLong DP, Losordo TM (2012) How to start a biofilter. Publication No. 4502, Southern Regional Aquaculture Center, Stoneville, MS

*Dumalan RJP, Bondoc KGV, Juinio-Meñez MA (2019) Grow-out culture trial of sandfish Holothuria scabra in pens near a mariculture-impacted area. Aquaculture 507:481-492

Eklöf JS, Msuya FE, Lyimo TJ, Buriyo AS (2012) Seaweed farming in Chwaka Bay: A sustainable alternative in aquaculture? In: de la Torre-Castro M, Lyimo TJ (eds) People, nature and research in Chwaka Bay, Zanzibar, Tanzania. Western Indian Ocean Marine Science Association, Zanzibar, p 213-234

* Eshchar M, Lahav O, Mozes N, Peduel A, Ron B (2006) Intensive fish culture at high ammonium and low $\mathrm{pH}$. Aquaculture 255:301-313

FAO (2017) Major boost for Zanzibar's aquaculture industry. www.fao.org/africa/news/detail-news/en/c/420823/ (accessed 3 August 2017) 
FAO (2020) Global aquaculture production. www.fao.org/ fishery/statistics/global-aquaculture-production/en (accessed 27 July 2020)

Felaco L, Olvera-Novoa MA, Robledo D (2020) Multitrophic integration of the tropical red seaweed Solieria filiformis with sea cucumbers and fish. Aquaculture 527:735475

Gelfand I, Barak Y, Even-Chen Z, Cytryn E, Van Rijn J, Krom MD, Neori A (2003) A novel zero discharge intensive seawater recirculating system for the culture of marine fish. J World Aquacult Soc 34:344-358

Gross A, Boyd CE, Wood CW (2000) Nitrogen transformations and balance in channel catfish ponds. Aquacult Eng 24:1-14

Guanzon NG Jr, De Castro-mallare TR, Lorque FM (2004) Polyculture of milkfish Chanos chanos (Forsskal) and the red seaweed Gracilariopsis bailinae (Zhang et Xia) in brackish water earthen ponds. Aquacult Res 35:423-431

Gutierrez-Wing MT, Malone RF (2006) Biological filters in aquaculture: trends and research directions for freshwater and marine applications. Aquacult Eng 34:163-171

Hair C, Foale S, Kinch J, Frijlink S, Lindsay D, Southgate PC (2019) Socioeconomic impacts of a sea cucumber fishery in Papua New Guinea: Is there an opportunity for mariculture? Ocean Coast Manage 179:104826

Hargreaves JA (1998) Nitrogen biogeochemistry of aquaculture ponds. Aquaculture 166:181-212

* Herbeck LS, Sollich M, Unger D, Holmer M, Jennerjahn TC (2014) Impact of pond aquaculture effluents on seagrass performance in NE Hainan, tropical China. Mar Pollut Bull 85:190-203

Heyman WD, Dobberteen RA, Urry LA, Heyman AM (1989) Pilot hatchery for the queen conch, Strombus gigas, shows potential for inexpensive and appropriate technology for larval aquaculture in the Bahamas. Aquaculture 77:277-285

Hochard S, Ducroq M, Lemonnier H, Royer F and others (2016) Holothurie : Lien entre performances de production et de bioremédiation dans le contexte de la crevetticulture en Nouvelle-Calédonie. Projet Hobical. Rapport du programme Zonéco. https://archimer.ifremer.fr/doc/ 00347/45798/

Holmer M, Fortes MD (2002) Impacts of milkfish (Chanos chanos) aquaculture on carbon and nutrient fluxes in the Bolinao area, Philippines. Mar Pollut Bull 44:685-696

*Holmer M, Duarte CM, Heilskov A, Olesen B, Terrados J (2003) Biogeochemical conditions in sediments enriched by organic matter from net-pen fish farms in the Bolinao area, Philippines. Mar Pollut Bull 46:1470-1479

Jana SN, Garg SK, Patra BC (2006) Effect of inland water salinity on growth performance and nutritional physiology in growing milkfish, Chanos chanos (Forsskal): field and laboratory studies. J Appl Ichthyology 22:25-34

Keuter S, Beth S, Quantz G, Spieck E (2017) Longterm monitoring of nitrification and nitrifying communities during biofilter activation of two marine recirculation aquaculture systems (RAS). Int J Aquacult Fish Sci 3:51-61

Kim E, Yoo S, Ro HY, Han HJ and others (2013) Aquatic toxicity assessment of phosphate compounds. Environ Health Toxicol 28:e2013002

K Klawonn I, Bonaglia S, Whitehouse MJ, Littmann S and others (2019) Untangling hidden nutrient dynamics: rapid ammonium cycling and single-cell ammonium assimilation in marine plankton communities. ISME J 13:1960-1974

Kleitou P, Kletou D, David J (2018) Is Europe ready for integrated multi-trophic aquaculture? A survey on the per- spectives of European farmers and scientists with IMTA experience. Aquaculture 490:136-148

* Lane DJW, Limbong D (2015) Catastrophic depletion of reef-associated sea cucumbers: resource management/ reef resilience issues for an Indonesian marine park and the wider Indo-Pacific. Aquat Conserv 25:505-517

* Largo DB, Diola AG, Marababol MS (2016) Development of an integrated multi-trophic aquaculture (IMTA) system for tropical marine species in southern Cebu, Central Philippines. Aquacult Rep 3:67-76

Lee S, Ferse S, Ford A, Wild C, Mangubhai S (2017) Effect of sea cucumber density on the health of reef-flat sediments. In: Mangubhai S, Lalavanua W, Purcell SW (eds) Fiji's sea cucumber fishery: advances in science for improved management. Wildlife Conservation Society, Suva, p 54-61

KLokhande VH, Nikam TD, Suprasanna P (2009) Sesuvium portulacastrum (L.) L. a promising halophyte: cultivation, utilization and distribution in India. Genet Resour Crop Evol 56:741-747

Lonard RI, Judd FW (1997) The biological flora of coastal dunes and wetlands. Sesuvium portulacastrum (L) L. J Coast Res 13:96-104

MacTavish T, Stenton-Dozey J, Vopel K, Savage C (2012) Deposit-feeding sea cucumbers enhance mineralization and nutrient cycling in organically-enriched coastal sediments. PLOS ONE 7:e50031

Magwa ML, Gundidza M, Gweru N, Humphrey G (2006) Chemical composition and biological activities of essential oil from the leaves of Sesuvium portulacastrum. J Ethnopharmacol 103:85-89

Marte CL (1988) Broodstock management and seed production of milkfish. In: Juario JV, Benitez LV (eds) Perspectives in aquaculture development in Southeast Asia and Japan: contributions of the SEAFDEC aquaculture department. Proceedings of the seminar on aquaculture development in Southeast Asia. SEAFDEC Aquaculture Department, Tigbauan, p 169-194

* Martins CIM, Eding EH, Verdegem MCJ, Heinsbroek LTN and others (2010) New developments in recirculating aquaculture systems in Europe: a perspective on environmental sustainability. Aquacult Eng 43:83-93

Maucieri C, Nicoletto C, Zanin G, Birolo M and others (2019) Effect of stocking density of fish on water quality and growth performance of European carp and leafy vegetables in a low-tech aquaponic system. PLOS ONE 14: e0217561

Mmochi AJ, Dubi AM, Mamboya FA, Mwandya AW (2002) Effects of fish culture on water quality of an integrated mariculture pond system. West Indian Ocean J Mar Sci 1: 53-63

* Moriarty DJW, Pollard PC, Hunt WG, Moriarty CM, Wassenberg TJ (1985) Productivity of bacteria and microalgae and the effect of grazing by holothurians in sediments on a coral reef flat. Mar Biol 85:293-300

Msuya FE (2013) Social and economic dimensions of carrageenan seaweed farming in the United Republic of Tanzania. In: Valderrama D, Cai J, Hishamunda N, Ridler N (eds) Fisheries and Aquaculture Technical Paper No. 580. FAO, Rome, p 115-146

Namukose M, Msuya FE, Ferse SC, Slater MJ, Kunzmann A (2016) Growth performance of the sea cucumber Holothuria scabra and the seaweed Eucheuma denticulatum: integrated mariculture and effects on sediment organic characteristics. Aquacult Environ Interact 8:179-189 
Naylor S, Brisson J, Labelle MA, Drizo A, Comeau Y (2003) Treatment of fresh-water fish farm effluent using constructed wetlands: the role of plants and substrate. Water Sci Technol 48:215-222

Patil AV, Lokhande VH, Suprasanna P, Bapat VA, Jadhav JP (2012) Sesuvium portulacastrum (L.) L.: a potential halophyte for the degradation of toxic textile dye, Green HE4B. Planta 235:1051-1063

* Pinheiro I, Arantes R, do Espírito Santo CM, do Nascimento Vieira F and others (2017) Production of the halophyte Sarcocornia ambigua and Pacific white shrimp in an aquaponic system with biofloc technology. Ecol Eng 100: 261-267

Poli MA, Legarda EC, de Lorenzo MA, Pinheiro I, Martins MA, Seiffert WQ, do Nascimento Vieira F (2019) Integrated multitrophic aquaculture applied to shrimp rearing in a biofloc system. Aquaculture 511:734274

Priborsky J, Velisek J (2018) A review of three commonly used fish anesthetics. Rev Fish Sci Aquacult 26:417-442

Primavera JH (2006) Overcoming the impacts of aquaculture on the coastal zone. Ocean Coast Manage 49:531-545

Purcell SW, Simutoga M (2008) Spatio-temporal and sizedependent variation in the success of releasing cultured sea cucumbers in the wild. Rev Fish Sci 16:204-214

* Purcell SW, Williamson DH, Ngaluafe P (2018) Chinese market prices of beche-de-mer: implications for fisheries and aquaculture. Mar Policy 91:58-65

Qiu T, Zhang L, Zhang T, Bai Y, Yang H (2014) Effect of culture methods on individual variation in the growth of sea cucumber. Chin J Oceanology Limnol 32:737-742

Quintã R, Santos R, Thomas DN, Le Vay L (2015) Growth and nitrogen uptake by Salicornia europaea and Aster tripolium in nutrient conditions typical of aquaculture wastewater. Chemosphere 120:414-421

R Core Team (2019) R: a language and environment for statistical computing. R Foundation for Statistical Computing, Vienna

Ranjan R, Megarajan S, Xavier B, Raju SS, Ghosh S, Gopalakrishnan A (2019) Design and performance of recirculating aquaculture system for marine finfish broodstock development. Aquacult Eng 85:90-97

Robinson G, Caldwell GS, Jones CLW, Slater MJ, Stead SM (2015) Redox stratification drives enhanced growth in a deposit-feeding invertebrate: implications for aquaculture bioremediation. Aquacult Environ Interact 8: $1-13$

Robinson G, Caldwell GS, Wade MJ, Free A, Jones CLW, Stead SM (2016) Profiling bacterial communities associated with sediment-based aquaculture bioremediation systems under contrasting redox regimes. Sci Rep 6: 38850

Robinson G, Caldwell GS, Jones CLW, Stead SM (2019) The effect of resource quality on the growth of Holothuria scabra during aquaculture waste bioremediation. Aquaculture 499:101-108

Rönnback P, Bryceson I, Kautsky N (2002) Coastal aquaculture development in eastern Africa and the Western Indian Ocean: prospects and problems for food security and local economies. Ambio 31:537-542

* Schneider O, Sereti V, Eding EH, Verreth JAJ (2005) Analysis of nutrient flows in integrated intensive aquaculture systems. Aquacult Eng 32:379-401

Sewell MA, Bergquist PR (1990) Variability in the reproductive cycle of Stichopus mollis (Echinodermata: Holothuroidea). Invertebr Reprod Dev 17:1-7
Shpigel M, Ben-Ezra D, Shauli L, Sagi M, Ventura Y, Samocha T, Lee JJ (2013) Constructed wetland with Salicornia as a biofilter for mariculture effluents. Aquaculture 412-413:52-63

Slama I, Messedi D, Ghnaya T, Savoure A, Abdelly C (2006) Effects of water deficit on growth and proline metabolism in Sesuvium portulacastrum. Environ Exp Bot 56: 231-238

Slama I, M'Rabet R, Ksouri R, Talbi O, Debez A, Abdelly C (2017) Effects of salt treatment on growth, lipid membrane peroxidation, polyphenol content, and antioxidant activities in leaves of Sesuvium portulacastrum L. Arid Land Res Manage 31:404-417

Stenton-Dozey JME, Heath P, Ren JS, Zamora LN (2020) New Zealand aquaculture industry: research, opportunities and constraints for integrative multitrophic farming. NZ J Mar Freshw Res, doi:10.1080/00288330.2020.1752266

Strickland J, Parsons T (1972) A practical handbook of seawater analysis. Fisheries Research Board of Canada, Ottawa

* Suantika G, Situmorang ML, Saputra FI, Putri SLE, Putri SP, Aditiawati P, Fukusaki E (2020) Metabolite profiling of whiteleg shrimp Litopenaeus vannamei from superintensive culture in closed aquaculture systems: a recirculating aquaculture system and a hybrid zero water discharge-recirculating aquaculture system. Metabolomics $16: 49$

Sumagaysay NS (1998) Milkfish (Chanos chanos) production and water quality in brackishwater ponds at different feeding levels and frequencies. J Appl Ichthyology 14:81-85

* Sumagaysay-Chavoso NS (2003) Nitrogen and phosphorus digestibility and excretion of different-sized groups of milkfish (Chanos chanos Forsskal) fed formulated and natural food-based diets. Aquacult Res 34:407-418

* Sumagaysay-Chavoso NS, San Diego-McGlone ML (2003) Water quality and holding capacity of intensive and semi-intensive milkfish (Chanos chanos) ponds. Aquaculture 219:413-429

Troell M, Hecht T, Beveridge M, Stead S and others (2011) Mariculture in the WIO region: challenges and prospects. WIOMSA Book Series No. 11. Western Indian Ocean Marine Science Association, Zanzibar

van der Gaag JJ, Paulissen MPCP, Slim PA (2010) Halophyte filters as saline treatment wetlands: applications and constraints. Alterra Report 2115. Alterra Wageningen UR, Wageningen

* van Rijn J, Tal Y, Schreier HJ (2006) Denitrification in recirculating systems: theory and applications. Aquacult Eng 34:364-376

Ventura Y, Wuddineh WA, Myrzabayeva M, Alikulov Z and others (2011) Effect of seawater concentration on the productivity and nutritional value of annual Salicornia and perennial Sarcocornia halophytes as leafy vegetable crops. Sci Hortic (Amsterdam) 128:189-196

*Verhoeven JTA, Meuleman AFM (1999) Wetlands for wastewater treatment: opportunities and limitations. Ecol Eng 12:5-12

*Vymazal J (2010) Constructed wetlands for wastewater treatment. Water 2:530-549

*Waller U, Buhmann A, Ernst A, Hanke V and others (2015) Integrated multi-trophic aquaculture in a zero-exchange recirculation aquaculture system for marine fish and hydroponic halophyte production. Aquacult Int 23: 1473-1489 
Wang Y, Gu X, Zeng Q, Mao Z, Gu X, Li X (2015) Fate of ${ }^{15} \mathrm{~N}$-enriched cyanobacteria feed for planktivorous fish in an enclosure experiment: a stable isotope tracer study. Fish Sci 81:821-830

Watanabe S, Zarate JM, Lebata-Ramos MJH, Nievales MFJ, Kodama M (2012) Utilization of organic waste from black tiger shrimp, Penaeus monodon, by sandfish, Holothuria scabra. In: Tanaka K, Morioka S, Watanabe S (eds) Sustainable stock management and development of aquaculture technology suitable for Southeast Asia. JIRCAS Working Report No. 75. Japan International Research Center for Agricultural Sciences, Tsukuba, p 81-86

Watanabe S, Kodama M, Orozco ZGA, Sumbing JG, Novilla SRM, Lebata-Ramos MJH (2015) Estimation of energy budget of sea cucumber, Holothuria scabra, in integrated multi-trophic aquaculture. In: Romana-Eguia MRR, Parado-Estepa FD, Salayo ND, Lebata-Ramos MJH (eds) Resource enhancement and sustainable aquaculture practices in Southeast Asia: challenges in responsible production of aquatic species. Southeast Asian Fisheries Development Center, Tigbauan, p 307-308

Watanabe S, Kodama M, Sumbing JG, Lebata-Ramos MJH (2017) Development of integrated multi-trophic aquaculture using sea cucumber. In: Ruenthal K, Olin P, Rust M, Trentacoste E (eds) Genetics in aquaculture: proceedings of the $42^{\text {nd }}$ US-Japan aquaculture panel symposium. NOAA Tech Memo NMFS-F/SPO-168

Editorial responsibility: Adam Hughes,

Oban, UK
Wolkenhauer SM, Uthicke S, Burridge C, Skewes T, Pitcher R (2010) The ecological role of Holothuria scabra (Echinodermata: Holothuroidea) within subtropical seagrass beds. J Mar Biol Assoc UK 90:215-223

*Wongkiew S, Hu Z, Chandran K, Lee JW, Khanal SK (2017) Nitrogen transformations in aquaponic systems: a review. Aquacult Eng 76:9-19

* Yogev U, Gross A (2019) Reducing environmental impact of recirculating aquaculture systems by introducing a novel microaerophilic assimilation reactor: modeling and proof of concept. J Clean Prod 226:1042-1050

* Yogev U, Sowers KR, Mozes N, Gross A (2017) Nitrogen and carbon balance in a novel near-zero water exchange saline recirculating aquaculture system. Aquaculture 467:118-126

* Zamora LN, Yuan X, Carton AG, Slater MJ (2018) Role of deposit-feeding sea cucumbers in integrated multitrophic aquaculture: progress, problems, potential and future challenges. Rev Aquacult 10:57-74

* Zhang J, Zhang S, Kitazawa D, Zhou J, Park S, Gao S, Shen Y (2019) Bio-mitigation based on integrated multi-trophic aquaculture in temperate coastal waters: practice, assessment, and challenges. Lat Am J Aquat Res 47:212-223

Zhong F, Liang W, Yu T, Cheng SP, He F, Wu ZB (2011) Removal efficiency and balance of nitrogen in a recirculating aquaculture system integrated with constructed wetlands. J Environ Sci Health A 46:789-794

Submitted: June 3, 2020; Accepted: September 4, 2020

Proofs received from author(s): October 29, 2020 